\title{
English and French Borrowed Words for Euphemism in Jordanian Arabic
}

\author{
Omar Hazaymeh $^{1}$, Husein Almutlaq ${ }^{1}$, Mufleh Jarrah ${ }^{1} \&$ Adam Al-Jawarneh ${ }^{1}$ \\ ${ }^{1}$ Al-Balqa Applied University, Al-Huson University College, Jordan \\ Correspondence: Omar Hazaymeh, Al-Balqa Applied University, Al-Huson University College, Jordan. E-mail: \\ omar1972@bau.edu.jo
}

\author{
Received: September 7, 2019 Accepted: September 28, 2019 Online Published: October 28, 2019 \\ doi:10.5539/ijel.v9n6p287 URL: https://doi.org/10.5539/ijel.v9n6p287
}

\begin{abstract}
The present study aims to investigate the use of certain English and French words for euphemism in Jordanian Arabic from a sociocultural and linguistics perspective. The study based on an analytical analysis where data were collected from different places by the researcher himself, family members, informants besides taking benefit from related and similar studies. The study findings show that many English and very few French words are manipulated by Jordanian Arabic speakers to soften the effect of using Arabic direct words which have hard effect on people when they are used to describe someone or something. It also finds that the English and borrowed loanwords are used for various euphemistic domains. The study covers the English and French words that could be collected for the purpose of exploring the use them as euphemisms in Jordanian Arabic.
\end{abstract}

Keywords: euphemism, Jordan, Arabic, borrowed words, English, French

\section{Introduction}

Euphemism is an important politeness strategy that aims to beautify and softness the toughness and hardness of using direct expressions and words that have tough and harmful effect on people or that are socially taboos. Euphemism is an expression intended by the speaker to be less offensive, disturbing, or troubling to the listener than the word or phrase it replaces. Euphemism with communicative function of evasiveness, politeness, and concealing, plays dual parts in everyday social lives (Li-Na, 2015). As in English and French, euphemism in Arabic is the softness and the using of a substitution of a tabooed or unfriendly word. It melds the hardness of words which are taken in highly consideration and respect in order to avoid any wrong use or understanding of such expressions.

Euphemism in Arabic covers different sociolinguistic areas such as religion, beliefs, sexual intercourse, illnesses, and death. For example, Elayyan (1994); Al-Khatib and Salem (2011); and Bani Mofarrej and Al-Abed Al-Haq (2015) investigated the euphemized expressions of death and found that euphemism is widely used to soften the negative harmful impression of death though to varying degrees. The use of euphemistic expressions in death situations is widely common to soften the negative harmful impression of death. Besides, such expressions would vary based on age, gender, region, and social background (Elayyan, 1994; Al-Khatib \& Salem, 2011; Bani Mofarrej \& Al-Abed Al-Haq, 2015).

Euphemistic expressions in Arabic for sex cover sexual organs, acts, and relations because such themes are very sensitive and tabooed in Arabic culture. Such expressions are used in both Arabic standard and vernacular language as alternatives of tabooed and sexual words to avoid embarrassment. In this context, various strategies such as silence, change of tone, prosody, eye contact, criticism of the interlocuter, and the use of long or a combination of words to euphemize tabooed subjects are manipulated (Al-Husseini, 2007; Khanfar, 2012; Azieb \& Qudah, 2016; Sa'd, 2017; Lesmana, 2018).

Health issues and problems are also milded by using euphemistic expressions to hide the suffering of fatal diseases such as cancer and mental illness. Human genitals and excretions are strongly avoided in public talks so they are softened by euphemism (Elayyan, 1994).

As a conservative society, Jordan people shift to euphemism in public and private gatherings particularly in mixed ones where men and women sit together as in universities, hospitals and coffee shops. Euphemism is a strongly demanded strategy by Jordanians to avoid embarrassing. The religious and social backgrounds oblige Jordanians 
to avoid direct words, so they lean to substitutional expressions. The present study will focus on the English and French loan words used for euphemism in Jordanian Arabic.

\subsection{What is Euphemism?}

People seek politeness and avoid embarrassing in front of others. Certain topics, words and expressions are tabooed or offensive ones which might be not suitable to mention or debate in public as men may find it unpleasant to talk about them in front of other men or women and the same for women (Rababah, 2014). As a strategy of politeness, people shift to euphemism to soften the tabooed harmful words. In fact, euphemism is a powerful linguistic tool that is strongly registered in our linguistic thought. People use euphemism individually and socially, as it permits them debating and mentioning taboos such as sex, death, morals, physical appearance, excretion or religion in a soften way (Mocanu, 2017). Euphemism is a safe face technique. Several factors affect using euphemism in Jordanian Arabic such as the social rank and the position of the speaker besides prestige, cultural and psychological restrictions, politeness-orientation, offence, profanity, fear, shame, superstition (Al-Azzeh, 2010; Jung, 2014).

\section{Problem Statement}

Politeness is demanded in private and public speeches. Taboo words and issues cause in many cases embarrassment for both the speaker and the listener in many cases, so people try to mild and soften the effect of taboo words and direct harmful words by euphemism. The present study aims to explore the use of some English and French lexical borrowings for euphemism in Jordanian Arabic.

\section{The Significance of the Study}

The present study claims to be a pioneer as it will give those who are interested in Jordanian Arabic a view of the English and French loanwords used in Jordanian Arabic for euphemistic purposes. The present study is significant because it can be claimed that it is the first one to the best of the researcher knowledge that discusses the sociolinguistic euphemistic uses of English and French loanwords in Jordanian Arabic.

\section{The Delimitation of the Study}

The present study is limited to the English and French loanwords in Jordanian Arabic that are used for euphemism. It is also limited to the English and French borrowed words used by Jordanians in their daily speech and not the standard literature.

\section{The Questions of the Study}

The study attempts to answer the following questions:

A. What are the English and French loanwords used for euphemism in Jordanian Arabic?

B. How are these English and French loanwords are used for euphemism in Jordanian Arabic?

C. What are the main euphemized topics of the English and French borrowed words in Jordanian Arabic?

\section{Methodology and Data Collection}

As a sociolinguistic study aims to analytically describe English and French languages linguistic interference in Jordanian Arabic at the level of semantics, the present study concentrates at using English and French loanwords for euphemism by Jordanians. The data were gathered through personal observation for different sources including Jordanian Arabic newspapers, websites, programs and series on Jordanian TV and radio channels, informants; mainly students, and family members. The data were arbitrary collected from locations such as schools, colleges, universities, private and public gatherings. The informants collected the English and French words that they could notice within the spontaneous conversations. Besides, literature about English and French linguistic interference in Jordanian Arabic was also reviewed. After collecting the English and French borrowed words from the informants and the other sources, they were categorized under various domains in order to investigate using them for euphemistic purposes in Jordanian Arabic. Thirty informants came from different Jordanian governorates including Irbid and Jerash in the north, Amman and Zarqa in the middle, and Karak and Aqaba in the south. The data were gathered over a period of six months from January 2019 to June 2019. Many English loanwords were collected whereas the French ones were very little because English language dominates Jordanian Arabic than French language due to the fact that Jordan maintains strong relations at all levels with the United Kingdom and the United States, besides that English language is a compulsory subject in the Jordanian curriculum from the kindergarten to the university and it is also the medium of instruction in the faculties of medicine, science, and commerce, whereas, French is not widely common. 


\section{Analysis and Discussion}

The following is a discussion of certain English and French loanwords used for euphemism in Jordanian Arabic. Using English and French borrowed words allow Jordanians to discuss taboo and/or unpleasant topics without being embarrassed.

\subsection{Euphemism for Cancer}

Diseases and illnesses are commonly associated with decay, loss of control and the fear of death, these three notions generally linked to taboo language (Jamet, 2018). It is part of effective medical and psychological treatment to reduce the harmful conditions, to promote the chances of recovery, and to stand with patients in hardships. Cancer is a fatal disease with hard effects on the patients and the people around them. It is very mandatory to soften the effect of this disease on the mental and psychological conditions of the sick ones. Although the Arabic word 'saratan, i.e., cancer' is commonly used in Jordanian Arabic, many people shift to the English borrowed word 'cancer' to soften the harmful effect of the Arabic word. The English loanword 'cancer' is used by all Jordanians and not only restricted to the specialists. The English euphemistic word 'cancer' is used by Jordanians in private and public gatherings. When one wants to say that a friend or a relative has cancer, he tries to say that in a sympathetic way and tries to soften the harmful effect of the Arabic word 'saratan' on the hearers by using the English substitution 'cancer'.

\subsection{Euphemism for Bathroom}

The aim of euphemism is to soften a situation or an object in agreeable and less harassment way. Actually, many words are considered tabooed ones or impolite to be used in public although they are part of the lexicon of any language. Taboo is the prohibition or avoidance in any society of behavior believed to be harmful to its members in that it would cause them anxiety, embarrassment, or shame (Wardhaugh, 2006). So, as an avoidance language and evasive politeness strategy, the English euphemistic borrowed words "toilet" and "W.C" are used in Jordanian Arabic. The Arabic word "mirhad i.e, bathroom" is very embarrassment so people avoid using it and shift to the English loanword "toilet". The English borrowed acronym "W.C water closet" is Arabized into "dawrat miyah; water closet".

\subsection{Euphemism for Sex}

Sex issues are strongly avoided in public gatherings in Jordan. Talking about such embarrassing issues is viewed as impolite and shameful when a person refers to them directly. Actually, there is silence surrounds these issues and usually people say them in low voice accompanied with smiles and laughs. Al-jins 'sex' is a very tabooed topic in Jordanian Arabic. It can be proclaimed that sex and sexual intercourse in Jordanian Arabic are used in much more figurative styles to soften the effect of this social issue on people. Sexual taboos have social restrictions on the individual's behavior because they evoke shame and embarrassment. Tabooed sexual intercourse language is offensive and against politeness standards of the society, therefore, it is strongly condemned and replaced by euphemisms. The word sex and all other related terms are avoided in Jordanian Arabic, especially when young children are present or when men and women sit or gather in one place, so speakers manipulate the language by using figurative expressions or borrowed words especially the English loanword 'sex' to send the message indirectly. To avoid saying or using direct words of sexual relation, Jordanians especially the young ones at universities shift to the English word sex as a euphemism for the Arabic equivalent 'al-jins'. Talking about porno films, Jordanians say 'aflam siks; sex films. A thrilling girl is described by saying 'bint siksyyeh; sexy girl'. Condom is euphemistically used in Jordanian Arabic instead of the Arabic substitution "a'azil; isolator".

\subsection{Euphemism for Undergarments}

Borrowing words from other languages is a way to evoke euphemism (Antoni, 2008). It does not mean that certain language has no word or expression for the similar matter. But such a word and or an expression are considered too obscene or explicit. By this reason, its way is needed in existing euphemism. Certain male and female undergarments have embarrassed Arabic names that would be tabooed ones when used in public. Jordanians shift to the English loan words as a euphemistic strategy to avoid embarrassment and shame. Actually, such Arabic words are considered indecent and saying them in public shows low social status, low class background and a lack of manners, politeness and respect. The English loanword 'flannel; faneala or falena in Jordanian Arabic' is a euphemism for the Arabic word "shalha; underwear flannel" which has a very embarrassment effect when used by people in public. The Arabic underwear 'kalsoan; shorts' is very offensive, and people avoid using it especially in front of women. As a result, people euphemize this cloth by using the English word 'shorts. Slip briefs underpant is shortened in Jordanian Arabic to 'slip' with the Jordanian Arabic 
pronunciation 'slib' is used to euphemize the Arabic word "kalsoan fakhathi; thigh slip briefs'. The French loanword 'soutien' is pronounced 'sityaneh' and is used as a euphemism for the Arabic equivalent 'sidryyah; bra'. The French loanword 'culottes' is pronounced 'kaloat' in Jordanian Arabic and is used to euphemize the Arabic word 'kalsoan sitati; woman shorts'. The French loanword 'maillot' is also used as a euphemistic expression for the Arabic word 'kalsoan'. Cut off shorts, and bikini are also used to euphemize the Arabic substitution 'kalsoan', whereas the English loanwords underwear and lingerie are used as euphemisms for 'malabis dakhilyya; undergarments'. The word lingerie is now used as shop sign by many shops that sell women undergarments.

\subsection{Euphemism for Mental Disorder}

The Arabic word 'majnoon; mad' is not pleasant. People who suffer from mental disorders are looked at with an eye of sympathy because they are not able to control their behaviors. Although the word 'majnoon' is used, many people shift to English loan words to euphemize the mental disorder of someone. The English loanword 'fuse is used in Jordanian Arabic to describe a crazy person euphemistically. People say 'imfayyez' instead of saying 'majnoon'. Other expression is 'fayyazat maa'uh; he got fuse. It is also used in Jordanian Arabic as fuzatuh darbeh; his fuses are off cutout. The relation between these English words and the euphemistic sense in which they are used in Jordanian Arabic is that when the electrical currency is cutout everything stops and so the one who loses his mental ability will be unable to behave well and everything will stop for him, so people use these English words euphemistically to describe such situation. In order to euphemize the Arabic word 'majnoon' another English loanword is used too. Hallucination is borrowed from English into Jordanian Arabic to euphemize madness. People say 'halwas, imhalwes, bihalwes' to euphemistically describe a person who behaves or speaks in unconscious way. Hysteria is another English loanword to euphemize madness in Jordanian Arabic. Instead of saying someone is crazy or mad, people shift to the English borrowed word 'hysteria' by saying 'hastar; be becomes hysteric, imhaster; he is hysteric'. The English loanword short breaker is euphemistically used in Jordanian Arabic as shorit, sharrat, imesharret to describe the one who loses his temper and starts behaving in unconscious way instead of saying majnoon; mad.

\subsection{Euphemism for Death}

Death is feared. It is a very harmful and shocked moment which makes people avoid talking about it directly and shift to different words are as safeguards to euphemize it. In all societies and almost all languages, "death", the most sensitive and fearful subject people try to avoid mentioning, is an extremely tabooed word. Different people, whichever cultural groups they belong to, can't feel ease about its gravity and dreadfulness (Qi, 2010). Jordanian people Arabize the English word visa as an Arabic verb (fayyaz, got a visa) as a euphemistic expression for the one who passed away.

\subsection{Euphemism for Lying}

Accusing someone of being liar is very shameful and unpleasant. It causes bad reputation which makes someone untrustworthy and cannot be trusted when saying anything. Actually, lying is very harmful in Jordanian society as it is in all other societies. People use euphemistic expressions to avoid using direct and harsh words that describe someone's speech is not true as lying is very understated and refused custom. The Arabic words 'kaththab, kathib both mean liar and kithib means lying' are used to show that a person is not telling the truth. The English borrowed word 'false' is pronounced 'falso' in Jordanian Arabic. It is euphemistically used to soften saying that someone lies. Jordanians say 'kalamu falso; his speech is false' to avoid saying 'kalamu kithib; his speech is lying'. Another English borrowed word that is used by Jordanian to euphemize lying, is fabrication 'fabrakah in Jordanian Arabic'. People say 'kalamo kulluh barakah; all his speech is fabrication'.

\section{Conclusion}

As is a strategy of politeness and avoiding embarrassment, euphemism is commonly used by people in their private and public meetings. It is actually a demanded strategy to save one's face. The present study aims at investigating the use of English and French loanwords for euphemism in Jordanian Arabic. The findings of the study showed that many English and very few French vocabularies are used by Jordanians for euphemism to avoid direct declaration of taboos and harmful expressions. The study also revealed that the English and French loanwords were of different euphemistic domains such as death and lying.

\section{Acknowledgments}

We would like to thank the informants for their valuable cooperation in collecting the data.

\section{References}

Al-Azzeh, I. (2010). The Use of Euphemisms by Jordanian Speakers of Arabic. Published MA Thesis. Middle East 
University- Jordan.

Al-Husseini, H. (2007). Euphemism in English and Arabic: A Contrastive Study (pp. 326-346). Paper presented at the 1st Scientific Conference of the faculty of education, University of Wassit, 18-19 February.

Al-Khatib, M. A., \& Sabbah, E. H. (2008). Language choice in mobile text messages among Jordanian university students. SKY Journal of Linguistics, 21, 37-65.

Al-Khatib, M. A., \& Salem, Z. (2011). Obituary announcements in Jordanian and British newspapers: a cross-cultural overview. Acta Linguistica, 5(2),80-96.

Azieb, S., \& Qudah, M. (2016). Soft-boiled speech: a contrastive analysis of euphemisms in Algerian and Jordanian Arabic. ВОПРОСЫ ТЕОРЕТИЧЕСКОЙ И ПРИКЛАДНОЙ ЛИНГВИСТИКИ Theoretical and Applied Linguistics, 2(4), 54-65.

Bani Mofarrej, O. M., \& Al-Abed Al-Haq, F. (2015). A sociolinguistic study of euphemistic death expressions in Jordanian Arabic. Arab World English Journal (AWEJ), 6(2), 110-130. https://doi.org/10.24093/awej/vol6no2.9

Elayyan, F. S. (1994). Variation in the use of euphemisms in Jordanian Arabic. Unpublished master's thesis. Yarmouk University, Jordan.

Jamet, D. (2018). The neological functions of disease euphemisms in English and French: verbal hygiene or speech pathology? Lexis Journal in English Lexicology, 12, 1-26. https://doi.org/10.4000/lexis.2397

Jung, K. Y. (2014). Euphemism in Arabic. Arabic Language \& Literature, 18(1), 1-18. https://doi.org/10.18630/kaall.2014.18.1.001

Khanfar, A. M. (2012). Euphemism in Arabic: typology and formation. Journal of the College of Arts, 61, 1-34.

Lesmana, M. (2018). Knowing taboo words and sexual euphemism in Arabic. Journal of Humanities and Social Science, 23(10), 87-90.

Li-Na, Z. (2015). Euphemism in modern American English. Sino-US English Teaching, 12(4), 265-270. https://doi.org/10.17265/1539-8072/2015.04.004

Mocanu, M. (2017). Taboo and euphemism in the religious language. International Letters of Social and Humanistic Sciences, 75, 1-9. https://doi.org/10.18052/www.scipress.com/ILSHS.75.1

Qi, G. (2010). Cultural differences in Chinese and English euphemisms. Cross-Cultural Communication, 6(4), 135-141.

Rababah, H. A. (2014). The translatability and use of x-phemism expressions (x-phemization): euphemisms, dysphemisms and orthophemisms in the medical discourse. Studies in Literature and Language, 9(3), 1-12.

Sa'd, S. H. T. (2017). A sociolinguistic analysis of taboos and euphemisms in an Arab community in Iran. Dialectologia, 18, 107-127.

Wardhaugh, R. (2006). An Introduction to Sociolinguistics (5th ed.). Blackwell Publishers Ltd.

\section{Copyrights}

Copyright for this article is retained by the author, with first publication rights granted to the journal.

This is an open-access article distributed under the terms and conditions of the Creative Commons Attribution license (http://creativecommons.org/licenses/by/4.0/). 